This item was submitted to Loughborough's Research Repository by the author.

Items in Figshare are protected by copyright, with all rights reserved, unless otherwise indicated.

\title{
A review of children's fitness testing
}

PLEASE CITE THE PUBLISHED VERSION

PUBLISHER

(c) Sage

VERSION

AM (Accepted Manuscript)

LICENCE

CC BY-NC-ND 4.0

REPOSITORY RECORD

Harris, Josephine P., and Lorraine Cale. 2019. "A Review of Children's Fitness Testing”. figshare. https://hdl.handle.net/2134/4466. 
This item was submitted to Loughborough's Institutional Repository (https://dspace.lboro.ac.uk/) by the author and is made available under the following Creative Commons Licence conditions.

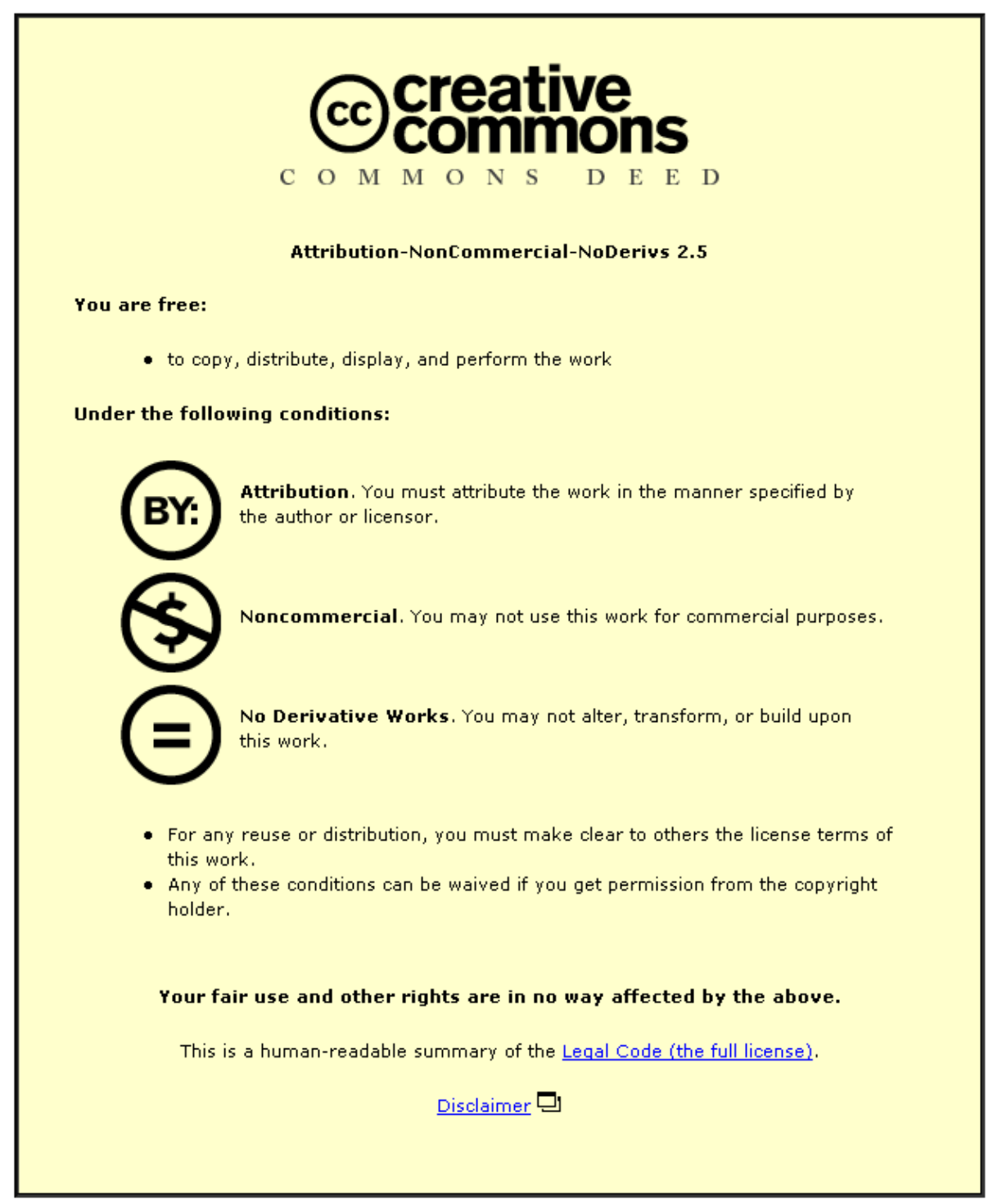

For the full text of this licence, please go to: http://creativecommons.org/licenses/by-nc-nd/2.5/ 
Title: A Review of Children's Fitness Testing

Jo Harris \& Lorraine Cale

Abstract

A review of literature on children's fitness testing formed part of a study exploring the feasibility of fitness testing children in order to promote their physical activity and health status. The review revealed that there is no empirical evidence to support concerns about low levels of fitness amongst children or a decline in children's fitness over time. Further, there is only weak evidence that physical fitness is related to children's current health although growing evidence that it may be related to future health. However, the measurement of children's fitness is problematic, given methodological limitations and the possible negative impact on some children. Additionally, the use of children's fitness test data to inform policy and practice is limited, and there is little evidence that large scale surveys on children's fitness have positively impacted on children's health, activity and fitness. Based on the review, recommendations are included for policy makers and practitioners which reflect the shift towards a stronger emphasis on physical activity within health promotion.

\section{Introduction}

This review has been prompted by concerns and anecdotal stories about low levels of fitness amongst today's young people and the possible consequences of this for their current and future health. Solutions to the 'problem' have included proposals to fitness test children and to use this 
information to improve their health status. Whilst there is no doubt that young people's health and fitness are important issues, the authors consider it equally important that policy makers and practitioners work from an informed base in order that any actions taken are relevant, meaningful and effective.

This paper summarises the literature on children's fitness testing which was reviewed as part of a feasibility study commissioned by the National Assembly for Wales conducted between October 2003 and March 2004. The specific aim of the study was to determine if there was a need and whether it was cost effective and practical to carry out a research project investigating the fitness levels of Welsh children. A key aspect of the methodology included a comprehensive review of the relevant literature to establish the key findings and issues associated with the fitness testing of children. A world wide literature search (confined to papers published in the English language) was carried out using metalib (a multi-database research tool - see Hamblin \& Stubbings (2003) for further information).

This paper focuses only on the main and consistent findings, trends and issues associated with: physical fitness and the associated health benefits in children, the physical fitness status of children, monitoring children's physical fitness, and the role of children's fitness testing in physical activity and fitness promotion. 


\section{Physical Fitness and the Associated Health Benefits}

Although a relationship between physical activity, physical fitness, and body fatness in children and adolescents has been confirmed (Boreham \& Riddoch, 2001), there is only weak evidence that physical activity and/or physical fitness are related to a healthy cardiovascular disease (CVD) risk profile in children and adolescents (Twisk, 2000).

Twisk (2000) also reported that there was no evidence that physical activity and/or physical fitness during childhood and adolescence are related to CVD risk factors in adulthood. However, evidence that fitness can influence future health has more recently come to light and is becoming more persuasive. Findings from a few studies (e.g., the Amsterdam Growth and Health Longitudinal Study (Twisk, Kemper \& Van Mechelen, 2002a); The Muscatine Study (Janz, Dawson \& Mahoney, 2002); The Northern Ireland Young Hearts Project (Boreham et al., 2002); The Danish Youth and Sports Study (Hasselstrom et al., 2002); and The Leuven Longitudinal Study on Lifestyle, Fitness and Health (Lefevre et al., 2002)) have suggested that high physical fitness during adolescence and young adulthood is related to a healthy risk factor profile later in life, but that physical activity levels do not influence CVD in later life (Twisk, Kemper \& Van Mechelen, 2002b).

There is also evidence that physical fitness and physical activity have a positive influence on young people's psychological health (Biddle, 1995; Calfas \& Taylor, 1994; Mutrie \& Parfitt, 1998; Tortolero, Taylor \& Murray, 2000). Following a review of 48 articles, Tortolero, Taylor and Murray (2000) found 
strong or moderate support for the relationship between physical activity and physical fitness in youth in several psychological variables such as self-efficacy, self-esteem, greater perceived physical competence, and decreases in depression and stress.

Riddoch (1998) concluded from his review that 'no single study, or set of studies, provides definitive evidence for a meaningful health gain through being an active child' (p. 30). Following a review of the evidence, Cale and Harris (2005) claimed that the same could be said for fitness. In other words, strong empirical evidence that physical fitness and physical activity during childhood have a major impact on current or future health is yet to be established. That said, the associations that do exist are in the healthy direction and the evidence is mounting. Given the strong and consistent relationships between activity or fitness and health in adults (such as reduced risk of hypertension, cardiovascular disease, obesity, osteoporosis and mental health conditions - see Department of Health, 2004), the paediatric origins of CVD, and the increasing prevalence of obesity in young people, it seems likely that adequate physical activity and physical fitness will benefit young people. However, Boreham \& Riddoch (2001) point out that judgements to date are based largely on limited paediatric data, a richer adult database, educated guesswork and basic physiological principles. Clearly, more substantial research evidence is needed before definitive conclusions can be drawn. Longitudinal studies though remain challenging in terms of costs, methodology and sustaining the continuing cooperation of participants over a long period of time. Until more evidence becomes available, the authors 
consider it unwise to conclude that lack of definitive data on the health benefits of youth physical activity and physical fitness means that neither is important for their health. Biddle and colleagues (2004, p.679) similarly summarise from their review of health-related physical activity in young people that 'although the evidence is unconvincing at times, several factors (such as the link between physical inactivity and obesity and the associated emergence of type II diabetes in youth) lead to the conclusion that promoting physical activity in youth is desirable'. Even adopting a precautionary perspective, it could be argued that, in the absence of adequate information to fully, and totally rationally, develop a policy based on scientific facts, advocating increased physical activity, even if it did no good, would arguably do no harm to children and adolescents.

\section{The Physical Fitness Status of Children}

\section{National Fitness Survey Findings}

Large scale national 'fitness' surveys on children have been conducted in the United States (The National Children and Youth Fitness Study I \& II (Ross \& Gilbert, 1985; Ross \& Pate, 1987); The 1985 President's Council on Physical Fitness and Sports Youth Survey (US Department of Health and Human Services, 1986), Canada, (The 1981 Canada Fitness Survey (Shephard, 1986); The 1988 Campbell Survey on Well Being in Canada (Stephens \& Craig, 1988; Torrance, 1991); The 2002 Survey of Well Being in Canada (see www.cflri.ca), Australia (The 1985 Australian Schools Health and Fitness Survey (Pyke, 1987)), and the UK (The 1989 Northern Ireland 
Fitness Survey (Division of Physical and Health Education, 1990)). A selection of these surveys are summarised in Table 1.

Insert Table 1: A Selection of Children's National Fitness Surveys

From a review of the methodology and findings from the various national fitness surveys, a number of points are worthy of note.

\section{Nature of the Surveys}

Although the studies are often referred to as 'fitness' surveys, this title is somewhat misleading as each represents more than a survey of children's fitness. Physical activity participation (in terms of activity patterns, habits and levels) also features strongly within the design of all studies. Indeed, more attention is generally afforded to reporting physical activity than fitness data. For example, the findings reported following the 1981 Canada Fitness Survey and the 1988 Campbell Survey on Well Being focus almost exclusively on physical activity. The 1988 findings reported for youth and young adults (Torrance, 1991) focused on physical activity levels, the context for physical activity participation, barriers to participation and attitudes towards physical activity. Further, where physical fitness results are reported, average scores on various test items tend to be reported, with no interpretation of their implications for children's health. In this respect, it could be argued that their value, in terms of their ability to influence policy and practice, is limited. Other notable components of the National Surveys include measures of lifestyle generally, as well as attitudes towards physical activity, exercise and sport. 


\section{Shift in Emphasis}

The above indicates a gradual shift in emphasis over the years from a focus on physical fitness to physical activity, and other lifestyle behaviours. The recognition of the importance of children's physical activity and other health behaviours is also reflected in more recent developments. For example, the third wave of the Canada Fitness Survey was re-named the '2002 Survey of Well Being in Canada' and did not address physical fitness. Rather, it investigated current involvement in physical activity, as well as social and environmental supports that were available for physical activity involvement. Questions about other lifestyle behaviours and general health and demographic were also included in order to examine trends over time.

In a similar vein, it is perhaps significant that there has been no follow up to the US National Children's Fitness Survey II. Instead, the National Youth Risk Behavior Survey (YRBS) appears to have taken its place. The YRBS was developed in 1990 to monitor priority health risk behaviours (e.g., inadequate physical activity, tobacco use, unhealthy dietary behaviours, alcohol and other drug use) that contribute to the leading causes of death, disability and social problems among youth and adults in the US. The YRBS is now conducted every two years and provides data representative of secondary aged students in schools throughout the US. Included in the results are trends in the prevalence of physical activity among young people (see for example, Department of Health and Human Services \& Centers for Disease Control and Prevention, 1996).

Possible reasons for the shift in emphasis away from measuring fitness to monitoring physical activity include: increased knowledge about the broad range of possible 
benefits of physical activity in all its forms, and growing awareness of the volume of activity required to bring about these benefits.

\section{Methodological Limitations}

It is important to note that limitations in the methodologies and test items adopted by these studies (and consequently the validity of the reported findings) have been widely acknowledged (and will be discussed later). The Northern Ireland Fitness Survey report highlights how 'caution must be exercised when comparing individual children's results with the population scores' (Division of Physical and Health Education, 1990, p.64), identifying some of the methodological limitations in fitness testing children (e.g., test results are largely genetically determined in children, reflect children's level of maturation, and are affected by motivation and test conditions). Furthermore, the report states:

'it should be noted that fitness levels do not necessarily reflect activity levels in children, and it is activity, because of its relationship with improved health, we are trying to promote (p. 67).

Similarly, following an analysis of the national fitness data collected on US youth, Corbin \& Pangrazi (1992) urge for a focus on efforts to help all children and youth meet reasonable and relevant physical fitness standards but suggest:

'it is short sighted to focus only on fitness levels. Of equal if not greater importance is the need to encourage and monitor regular physical activity' (p.105). 


\section{Laboratory Based Fitness Test Findings}

The laboratory based measurement of young people's aerobic fitness has been afforded a good deal of attention over the years with the first studies being conducted between 50 and 67 years ago (Astrand, 1952; Morse, Schlutz \& Cassels, 1949; Robinson, 1938). These have since been supplemented by a number of cross sectional and longitudinal studies (Armstrong \& Welsman, 1997; Armstrong \& Van Mechelen, 1998). Recent reviews have summarised the data available (e.g., Armstrong \& Welsman, 1994; Cale \& Harris, 2005; Rowland, 2002; Welsman \& Armstrong, 1996, Armstrong \& Welsman, 1997; Armstrong \& Van Mechelen, 1998; Armstrong \& Welsman, 2000a; 2000b). Recently, Cale and Harris (2005, p. 32) have highlighted the following key findings and trends in this data:

- Young people show a progressive, almost linear increase in peak $\mathrm{VO}_{2}$ with age, although some studies show that from about 14 years, girls' peak $\mathrm{VO}_{2}$ levels off or declines.

- With body size appropriately controlled for, boys' peak $\mathrm{VO}_{2}$ increases through childhood and adolescence and into early adulthood, whilst girls' increases into puberty and then levels off.

- Whilst data are limited, evidence indicates that maturation induces increases in peak $\mathrm{VO}_{2}$ in both sexes, independent of those explained by body size, body fatness and age.

- Boys' peak $\mathrm{VO}_{2}$ is higher than girls' at least from late childhood, and there is a progressive divergence in boys' and girls' values during the teenage years. 
- There is no evidence to suggest that low levels of aerobic fitness are common amongst children.

- There is no convincing evidence to suggest that children's aerobic fitness has declined over time.

\section{Are children unfit and has their fitness declined?}

Although the popular media has reported that young people are 'unfit' and/or their aerobic fitness has declined over the years, the evidence summarised above clearly suggests that this is not the case. On this issue, Corbin (2002, p.139) proposes that the media 'likes bad news' and that 'much talk about lack of fitness of our youth is hyperbole.... Whilst there is no consensus with respect to the optimal level of physical fitness for young people, experts within the European Pediatric Work Physiology group have suggested that it may be possible to express a lower limit of peak $\mathrm{VO}_{2}$ that, in the absence of other health-related problems, may represent a 'health risk' (Bell et al., 1986). Risk levels of $35 \mathrm{ml} \mathrm{kg}^{-1} \mathrm{~min}^{-1}$ and $30 \mathrm{ml} \mathrm{kg}^{-1} \mathrm{~min}^{-1}$ were proposed for boys and girls respectively. Whilst few studies have reported results in sufficient detail to determine the percentage of young people falling below these thresholds, some estimates have been made. For example, a re-analysis of data collected over a ten year period on over 2500 young people in relation to these 'health risk' thresholds revealed that only about two per cent of young people aged 9-16 could be classified as at risk (Armstrong et al., 1990; Armstrong et al., 1991; Armstrong et al., 1996), whilst another study of prepubertal children reported that all had values above the 'health risk' threshold (Armstrong et al., 1995). Furthermore, in analysing the mean values obtained in longitudinal studies of aerobic fitness, it is evident that all comfortably exceed the health risk threshold values proposed by Bell 
et al., (1986) (see Armstrong \& Van Mechelen, 1998). Thus, there appears to be no evidence to suggest that low levels of aerobic fitness are common amongst young people.

According to Rowland (2002), the notion that physical fitness (and physical activity) have been decreasing in youth over the last half century has been supported by professional opinion as well as public perception. He questions however, whether the decline in aerobic fitness is fact or supposition.

Based on an analysis of data over almost six decades, Armstrong \& Welsman (1997) and Armstrong \& Van Mechelen (1998) report that there is no scientific evidence to suggest that young people's aerobic fitness has declined over the last 50 years. Rather, they noted how the aerobic fitness of young people appears to have remained remarkably consistent over time, with the current data closely reflecting the findings of earlier studies.

Following an analysis of children's fitness test data in the United States, Corbin \& Pangrazi (1992) suggested that there was little, if any, evidence to indicate that children and youth were less fit than in previous decades. They explained that the only health-related measures of fitness studied over time include field pull ups and the flexed arm hang tests which showed no decrease in test scores. Likewise, following his review of the evidence, Rowland (2002) concluded that the existing research literature does not permit any confident conclusions to be drawn regarding temporal changes in aerobic fitness. He reviewed changes in aerobic fitness in 
youth, as defined by both endurance performance and maximal aerobic power, suggesting that studies of changes in endurance performance, as measured via fitness test batteries, have provided conflicting and not particularly convincing findings. With respect to aerobic power, Rowland (2002) summarised the data from a number of studies of boys over a 30 year period which confirmed the findings of Armstrong \& Welsman (1997) and Armstrong \& Van Mechelen (1998). No obvious changes in either direction were evident, and the values were remarkably similar to those reported by Robinson in 1938. As a result, he declared that there is no evidence that $\mathrm{VO}_{2}$ max values in children have changed over the years.

These conclusions are based on rigorous and properly controlled and administered studies as opposed to perceptions based on field-based measures and results gathered locally with possibly less standardisation and greater degrees of variation and subjectivity in the assessment process. Nevertheless, they need to be considered in light of the known limitations with the data and in the measurement and interpretation of young people's physical fitness, as determined via aerobic fitness. For example, no information is available on randomly selected groups of children, and since volunteers are generally used as subjects in studies, selection bias cannot be ruled out (Armstrong \& Welsman, 2000a). Rowland (2002) similarly acknowledges the limitations with data that is not population representative. With respect to analysing temporal changes in aerobic fitness, he also cautions the comparison of data over time from different laboratories with different equipment, protocols and staff. Given the limitations, he claims that trying to detect small changes in fitness 'would seem almost impossible' (Rowland, 2002, p.6). 
A further issue relates to the influence of heredity or genetic potential and maturation on young people's aerobic fitness. Indeed, on the issue of changes in aerobic fitness over time, Blair (1995) suggested that it is unlikely that significant population changes would occur in such genetically determined performance characteristics. Further, because extra adipose tissue serves as a load which must be transported during weight bearing activity, increases in body weight and body fatness associated with maturation will, if not accounted for, have a negative influence on tests of aerobic capacity (Rowland, 2002).

\section{Monitoring Children's Physical Fitness}

Physical fitness comprises health-related and performance (skill)-related components (Caspersen, Powell \& Christenson, 1985) which can be measured via laboratory or field based fitness tests with children. The health-related components of fitness (i.e., cardiovascular fitness, muscular strength and endurance, flexibility and body composition) are of particular interest because they are related to specific 'health' or disease outcomes (Pate, 1988).

Physical fitness monitoring has been employed with children for a number of years. However, the methodological problems of assessing children's physical fitness have been widely acknowledged (see for example, American College of Sports Medicine (ACSM), 1988; Armstrong, 1987; 1989; Cale \& Harris, 1998; Fox \& Biddle, 1986; Physical Education Association (PEA), 1988; Rowland, 1995; Seefeldt \& Vogel, 1989).

\section{Purposes of Measuring Children's Physical Fitness}


Fitness testing in children can serve a number of purposes within school and research contexts. Within the school setting, purposes include:

- programme evaluation

- motivation

- identification of children in need of improvement

- identification of children with potential

- screening

- diagnosis of fitness needs for individual exercise prescription and improvement

- the promotion of physical activity, goal setting, self-monitoring and self-testing skills

- cognitive and affective learning

(Pate, 1994; Whitehead, Pemberton \& Corbin, 1990).

In terms of research, fitness testing is considered important for the following reasons:

- to achieve a better understanding of fitness phenomena and their demography

- to investigate the effects of training on children's fitness

- in the public health context, to survey the fitness levels of children on a large scale in order to provide baseline measures from which to analyse the healthrelated fitness of a population

(Fox \& Biddle, 1986).

\section{Measures of Physical Fitness}

Whilst laboratory based assessments are generally assumed to provide more accurate measures of children's fitness, due to cost and practicality, their use is 
limited in terms of assessing fitness on a large scale and in terms of physical activity promotion practice. Attention here therefore, will be afforded only to field based measures of fitness.

\section{Field Based Measures of Physical Fitness}

Physical fitness testing in the field typically involves the administration of a battery of simple tests to evaluate different components of fitness (ACSM, 2000). The most common field tests of physical fitness for children include:

- Aerobic fitness/capacity tests: distance/timed walks/runs; step tests; multistage fitness test

- Muscular strength/endurance: sit ups/curl ups and/or the progressive abdominal sit up (curl) test; pull ups and/or modified pull ups; push ups

- Flexibility: sit and reach; shoulder stretch; arm lift

- Body Composition: body mass index (BMI); skinfold thicknesses; girth measures.

Whilst some surveys, schools, and communities may develop their own tests, test batteries and standards of performance to assess physical fitness (Ross, 1989), a number of formal fitness tests batteries have been developed over the years. These have been devised predominantly in the US, though test batteries have also been developed in other countries such as Canada, Australia and Europe, an example of the latter being the European Test of Physical Fitness - EUROFIT - designed by the Council of Europe Committee for the Development of Sport in 1988 (Fox \& Biddle, 1986). The major batteries measure common components of health-related fitness 
with many including the same or similar tests (Safrit, 1990). In essence, they are more alike than they are different (Pate, 1994; Safrit, 1990).

The fourth version of FITNESSGRAM which is a comprehensive health-related fitness and activity assessment and computerized reporting system (The Cooper Institute for Aerobics Research, 1999), has perhaps become the most established and well known fitness test battery. It is designed to educate young people about their physical fitness and includes various components of fitness, with several test options and one recommended item. FITNESSGRAM uses criterion referenced standards to evaluate performance which is classified in two general categories, 'Needs improvement' and 'Healthy Fitness Zone.' The report generates personalized output and recommendations based on the results. Additional features include a physical activity assessment and a recognition programme 'You Stay Active.'

\section{General Critique of Field Based Fitness Tests and Test Batteries}

A number of advantages and disadvantages associated with field tests have been identified within the literature (see Bar-Or, 1993; Bouchard et al., 1992; Docherty \& Bell, 1990; Fox \& Biddle, 1986; Pangrazi, 2000; Pangrazi \& Corbin, 1990; Pate, 1994; PEA, 1988; Rice \& Howell, 2000; Rowland, 1995; Safrit, 1990; Safrit \& Looney, 1992) which are common to all tests and to fitness test batteries in general. For example, advantages include: 
- tests are generally easy to administer and time efficient.

- tests are relatively safe and involve minimal equipment and low cost.

- considerable thought has been given to the scientific evidence supporting tests and there have been advances in the development and use of physical fitness tests for children.

- emphasis is now on the evaluation of health-related fitness components and has shifted in recent years from testing in isolation, to an educational programme with testing as an integral part.

- many physical fitness programmes are now packaged attractively and include test manuals, curricular guidelines and instructional materials to assist the user/teacher.

- some programmes have computerized feedback systems.

Disadvantages include:

- the appropriateness of some fitness tests for use with children is questionable (e.g., the Multistage Fitness Test was developed for use with elite, adult populations).

- a child's metabolic, cardiopulmonary, thermoregulatory, and perceptual responses to exercise are different from those of adults and a different approach may therefore be required in administering tests to children.

- field tests provide only a crude measure of an individual's physical fitness and are not considered suitable for the assessment of single, basic, physiological functions. 
- the reliability and validity of some fitness tests for use with children is questionable and the need for additional evidence of the reliability and validity of tests and test batteries has been identified.

- concerns about reliability and validity are associated with a requirement for administrative rigour (protocol adherence) and teachers' relatively limited direct experience of test administration.

- concerns about reliability and validity also stem from the fact that many factors influence children's performance on fitness tests and will be reflected in fitness test scores, namely:

- the environment/test conditions (temperature, humidity, wind speed/direction)

- lifestyle (exercise/nutrition)

- test protocol/procedures

- motivation

- intellectual and mechanical skill at taking the test

- heredity or genetic potential

- maturation.

The relative contribution of these factors varies from test to test, and between testing sessions though heredity or genetic potential and maturation are considered to most strongly influence test results.

Furthermore, there is much debate over and limitations in the practice of applying norm and/or criterion referenced standards (Cureton, 1994; Cureton \& Warren, 1990; Armstrong \& Welsman, 1997). Normative standards which relate scores with that of 
a reference group permit quick and simple comparisons to be made with children of the same sex and chronological age. However, they do not indicate desired levels of fitness and they confound the issue of relative fitness by failing to take maturation into account. In addition, they tend to promote ego orientation and imply that 'more is better'. Yet, criterion referenced standards which specify the minimum levels of fitness thought to be required for health also have their advantages and disadvantages. The former include the fact that they categorise individuals into groups that either meet or exceed minimum standards and those that do not, and communicate the accurate message that there is a level of fitness that is satisfactory for health which is below that needed to be a successful athlete. However, the validity of criterion referenced standards has been questioned with some considering that the use of somewhat arbitrary standards could lead to misclassifications of fitness, which may have negative consequences for some children. It is also claimed that criterion referenced standards may not provide enough of an incentive for young people to achieve higher fitness levels.

In summary, the numerous limitations have led to the conclusion that much of the data generated by fitness tests (both laboratory and field based) are not capable of rigorous interpretation. In particular, Armstrong (1995) and Armstrong \& Biddle (1992) recognize the importance of both maturation and motivation to children's test scores and claim that fitness tests simply determine the obvious, at best only distinguishing the mature and/or motivated from the immature and/or unmotivated. Clearly, if fitness testing is to provide meaningful data, then measurement techniques need to be valid, reliable and practical. As this review reveals, there are a number of measurement issues and limitations and the reliability and validity of 
many tests have not been established with children. In the words of Safrit (1990, p.25), it would seem that 'much still needs to be done' to improve the validity, reliability, practicality and thereby utility of fitness testing in young people.

\section{The Role of Fitness Testing in Physical Activity and Physical Fitness Promotion}

Methodological limitations aside, a number of other issues have been raised and concerns expressed over the use of fitness tests with children (see ACSM, 1988; Armstrong, 1987; 1989; Cale \& Harris, 1998, 2005; Fox \& Biddle, 1986; Harris, 2000; Harris \& Cale, 1997; PEA, 1988; Rowland, 1995; Safrit, 1990; Seefeldt \& Vogel, 1989).

\section{Fitness Testing Paradoxes}

A number of paradoxes relating to fitness testing have been reported in the literature (Cale \& Harris, 1998; Safrit; 1990; Seefeldt \& Vogel, 1989) which raise questions over the relative merits of testing. For example:

- fitness tests purport to assess health-related physical fitness yet do not provide any clinical measures of health status (e.g., blood pressure, blood lipids).

- fitness tests emphasize safe healthy practice yet some involve children performing tests which violate healthy behaviour. Safrit (1990) explains that, whilst batteries claim to encourage the development of and maintenance of good fitness behaviours, the tests themselves do not always reflect this behaviour. For example, exercising to exhaustion as in the Multistage Fitness test is not recommended practice, nor is executing as many sit ups as possible 
in one minute. Indeed, Cale \& Harris (2002) go so far as to suggest that these tests not only violate healthy behaviour, but common sense.

- some fitness tests involve maximal exertion yet the recommended intensity of physical activity for young people's health is 'at least moderate intensity' (Health Education Authority, 1998).

- in many public settings (e.g. health promotion environment, higher education), there is increasing rigour, emphasis and attention paid to screening and to ethical issues yet the school setting does not seem to engage in formal ethical approval or health screening procedures prior to involving pupils in fitness testing regimes which include maximal testing (see also Baalpe, 2004, p. .212).

- fitness tests deprecate performance as a component of health-related fitness, yet in most test items, performance is used as a basis for assessing fitness.

- the implications of fitness test performance for young people's health are not yet well established.

\section{Misunderstandings}

It is often assumed that fitness in children is primarily a reflection of the amount of activity performed, and that those who score high on fitness tests are active and those who do not are inactive (Pangrazi, 2000). These assumptions are inaccurate. The relationship between fitness and physical activity is low among children (Armstrong \& Welsman, 1997) and a child's activity level cannot be judged from his or her fitness level (Corbin, 2002). Corbin (2002) summarises some of the problems that can arise if fitness test scores are linked to activity levels. On the one hand, an active child who scores poorly on a test may become disappointed, disillusioned, demotivated and 'turned off' activity because he/she feels it does not 'pay off.' Equally, an inactive child 
who scores well may be delighted with the outcome, conclude that everything is fine when it is not, and consequently may not be motivated to change (Corbin, 2002).

There is a seeming paradox in that there is no well-established correlation between fitness and physical activity in children whereas in adults the relationship appears to be clearer. This may be due to a number of factors, such as young people having not lived long enough for their inherited body systems to be affected by their lifestyle behaviours, or the methods of measuring fitness and/or physical activity being too crude or perhaps not measuring what is required, and/or the limited understanding about what happens at the micro-level in the muscles of young people. Clearly, there remains much to learn about the underlying reasons for the somewhat surprising low correlation between physical activity and physical fitness in young people.

\section{Impact on Children and Children's Physical Activity Levels}

Another important consideration is how test procedures might affect the social, emotional, and attitudinal values of young people towards activity (Cale \& Harris, 2002; Seefeldt \& Vogel, 1989) as these in turn are likely to influence participation. Concern has been expressed that fitness testing may be counterproductive to the promotion of active lifestyles in young people (Docherty \& Bell, 1990; Corbin, Pangrazi \& Welk, 1995; Rowland, 1995). According to Rowland (1995), fitness tests are antitethical to the goal of promoting physical activity in children in so far as they can be demeaning, embarrassing and uncomfortable for children (often those about whom there is most concern), and may reinforce the notion that exercise is competitive and unpleasant. Docherty \& Bell (1990) and Corbin, Pangrazi \& Welk (1995) suggest that testing done improperly may turn many youngsters 'off' rather than 'on' to activity, and 
should therefore be discontinued. Tests may also communicate a false message to young people, namely that competition and excellence are necessary for health and fitness, which may further confound the goal of promoting physical activity (Cale \& Harris, 2005).

Advocates of physical fitness testing argue that testing motivates young people to maintain or enhance their physical fitness or physical activity levels, increases knowledge, and promotes physical activity via fostering positive attitudes. However, limited attention has been paid to the motivational effects of fitness testing on children or children's perspectives of, or knowledge and/or attitudes towards, fitness tests (Fox \& Biddle, 1988; Jackson, 2000).

Whitehead \& Corbin (1991) investigated the effect of fitness testing on motivation in youth and found that intrinsic motivation increased as a result of positive feedback after the test but decreased following negative feedback. Goudas, Biddle \& Fox (1994) found that different children have different motivational reactions to fitness testing depending on their achievement goal orientation, performance and perceived success. They concluded that the effects of fitness testing are complex and that motivational enhancement following testing cannot be taken for granted. Likewise, the Physical Education Association (PEA) has also noted that there is no hard evidence that fitness tests motivate individuals and suggest that in parallel areas of education, there is evidence that tests only motivate those who do well (PEA, 1988).

With regards to knowledge and attitudes, Hopple \& Graham (1995) investigated what children 'thought, felt and knew about' the mile run test. They revealed that children 
generally showed little or no understanding of why they were being asked to complete the test and many disliked taking it, viewing it as a painful, negative experience to be either actively or passively 'dodged.' Further, a study of adolescents' attitudes toward school PE revealed that young people viewed fitness testing unfavourably and as a major contributor to negative attitudes towards physical education (Luke \& Sinclair, 1991).

\section{An Over Emphasis on Fitness and the Fitness Versus Activity Debate}

There is also concern that the administration of fitness tests could lead to more attention being given to product related issues such as 'fitness' and 'performance' than to process-oriented issues such as 'health' and 'physical activity' behaviour (Cale \& Harris, 2002; Harris \& Cale, 1997). Certainly, an over emphasis on fitness is evident within media messages with consistent calls for efforts to 'get children fitter.' However, from a public health and physical activity promotion perspective, it is argued that the goal should be to influence the 'process', i.e., physical activity, rather than the 'product' of fitness. More recently and for various reasons, researchers have advocated the promotion (and assessment) of physical activity rather than physical fitness (Cale \& Harris, 2002; 2005; Cavill, Biddle \& Sallis, 2001; Corbin, 2002; Pangrazi, 2000; Riddoch \& Boreham,1995; Rowland, 1995). Reasons include:

- there is no evidence that low levels of aerobic fitness are common amongst young people or has declined over the past 50 years, yet there is evidence that many young people are inactive and a sizeable proportion do not meet current physical activity recommendations.

- the contributions to fitness of genetic influences and maturational status. 
- the idea that physical fitness is a paramount goal for children is a misconception and routine field testing is 'archaic and inconsistent with our current understanding of the exercise-health connection' (Rowland, 1995, p.125).

- focusing too much on fitness may be counterproductive and have as many negative consequences as positive ones.

- the focus on raising fitness levels which was common practice for many years, has been unsuccessful.

- in contrast to physical fitness (an attribute), increased physical activity (a behaviour) is an outcome that can be accomplished by all children regardless of ability (or disability) or personal interests, and will further benefit those young people who need it most. Because physical activity monitoring is free from genetic and maturational influences, it effectively 'levels the playing field' allowing all to succeed.

- a shift in promoting physical activity is more likely to be acceptable to the general public, particularly to those who are sedentary or have low fitness levels.

Another factor relevant to this debate is whether one is more important to health than the other, i.e., is fitness or activity more important to health? According to Boreham \& Riddoch (2001), this question remains unresolved. Nonetheless, the evidence that fitness is related to health itself, without being mediated by physical activity, is becoming increasingly persuasive and high cardiorespiratory fitness may be directly related to improved health status (Boreham \& Riddoch, 2001). As acknowledged earlier, recent findings 
suggest that high physical fitness during adolescence and young adulthood is related to a healthy CVD risk profile in later life, but that physical activity levels do not influence CVD risk in later life (Twisk, Kemper \& Van Mechelen, 2002b). This could lead some to conclude that from the point of view of future health, it may be better to focus on physical fitness rather than physical activity in youth. Certainly, it would seem to suggest that physical fitness should not be abandoned. However, this association may in part be genetically determined and be independent of activity. For instance, a high fit individual could inherit better health status and conversely a low fit individual could be unfortunate to have poorer health. According to Boreham \& Riddoch (2001), an alternative, but not mutually exclusive explanation might be that fitness acts as a marker for high activity, which might not only improve cardiovascular function, but also promote changes in other health indicators (e.g., lower blood pressure).

In summary, whilst both physical fitness and physical activity are desirable for young people and promoting both should be beneficial (if approached in an appropriate way), for the reasons outlined above, if resources and/or time are limited, more attention and energy might be better devoted to focusing on 'activity' than to 'fitness'.

\section{Implementation of Fitness Tests}

With respect to fitness testing in the curriculum, concerns have been expressed over the way in which fitness tests are implemented and conducted. According to Pate (1989), too often tests have been an almost irrelevant adjunct to the curriculum. Also, they often dominate programmes and in some cases constitute the entire fitness 
education programme. The amount of curriculum time spent on fitness testing without necessarily positively influencing young people's activity levels or their attitudes towards physical activity has also been criticised (Cale \& Harris, 2002; Harris \& Cale, 1997). The time spent on performing and scoring fitness tests may detract from promoting the process of being active (Harris, 2000), and may be at the expense of time spent on more useful activity promoting activities, and of developing knowledge and understanding about physical fitness and what physical fitness tests measure. Administering fitness tests simply to acquire data, without attention to its' educational role is not advised (Harris, 2000), this role being to develop knowledge about health, activity and fitness (e.g. how much activity is recommended for health; the health benefits of different types of activities; how to monitor physical activity and physical fitness; where activity opportunities are in the community), and to increase competence and confidence in relation to physical activity, and promote positive attitudes towards being active.

\section{Misuse of Fitness Test Scores}

Finally, concerns have been expressed over the possible inappropriate or undesirable use of fitness test scores. For example, within the curriculum, test scores in the past have been used to grade children as a primary indicator of achievement, to evaluate teacher competence, or as a measure of the success of an institution or programme (Corbin 2002; Corbin, Pangrazi \& Welk, 1995). Employing fitness tests for such purposes has been challenged (Corbin, 2002; Corbin, Pangrazi \& Welk, 1995) with warnings that it could have the following potential negative consequences:

- loss of interest in PE and physical activity

- teaching to the test 
- student and teacher 'cheating' on fitness tests (e.g. students performing exercises in a non-standardised manner to maximise their scores and teachers permitting this to happen)

- undermining the confidence of students who find that, even with effort, they cannot achieve the fitness goals necessary to get good grades or to meet teacher expectations

(Corbin, 2002, p.134 \& 135).

\section{Fitness Testing Recommendations}

Without careful consideration of the above issues and concerns, plus the methodological problems highlighted earlier, physical fitness testing can be fruitless and/or counterproductive to physical activity and fitness promotion. As previously noted, testing can be unpleasant, embarrassing and meaningless for many young people, and scores can be inaccurate, and thereby potentially misleading, unfair, and demotivating. In this respect, some have and others may decide to abandon fitness tests in favour of alternative methods of assessing children such as monitoring their knowledge, understanding, and attitudes towards physical activity and health and their physical activity and other health behaviours. Corbin, Pangrazi \& Welk (1995) are of the view that fitness testing might survive only if it can be shown that it promotes the right philosophy.

Cale and Harris (2005) consider that there is no reason why fitness testing cannot promote the right philosophy, and they claim that, if appropriately employed, and provided all relevant factors are taken into account, fitness testing can play a valuable role in the promotion of physical activity and in educating children about physical 
activity and fitness. Fitness testing and monitoring might be valuable components of a health-related fitness programme if used to: encourage positive attitudes towards health-related fitness; increase understanding of the principles underlying healthrelated fitness; and promote a lifetime commitment to health-related fitness' (PEA, 1988, p.194). So, despite the fact that fitness tests per se and associated scores have their limitations, it is the view of the authors that the potential cognitive, affective and behavioural benefits of the process (especially in an educational setting with informed and caring professionals) can outweigh the disadvantages; however, this depends primarily on 'how' it is implemented.

To achieve these benefits, clear guidance on the use of fitness testing in children is needed. Surprisingly though, despite its popularity over a number of years, there is little research to guide teachers in deciding how best to employ fitness testing with children. Limited attention has been paid to understanding how children respond to fitness tests or how tests can best be used to attain important educational and physical activity promotion objectives (Cale \& Harris, 2005). Recommendations concerning the implementation of fitness testing with young people have been made by a number of researchers and professional organizations (e.g., American Alliance for Health, Physical Education, Recreation and Dance (AAHPERD), 1999a; 1999b; 1999c; ACSM, 1988; Corbin, Pangrazi \& Welk, 1995; Harris, 2000; Harris \& Elbourn, 1994; Pate, 1994; Pate \& Hohn, 1994), but these have been based more on common sense than on scientific evidence. A summary and interpretation of the key recommendations and messages found in the literature has been made by Cale and Harris (2005), these include: 
- Fitness testing procedures should be child-centred, developmentally appropriate and accessible for all children. Tests designed for adults should be avoided or modified.

- Fitness testing should be a positive and meaningful experience presented in an individualised manner that provides children with personalised baseline scores and feedback from which to improve their activity and fitness levels.

- Personal improvement or maintenance over time should be the focus, not comparison with others. This takes account of individual differences and the fact that changes during puberty can result in a 'flattening' or reduction in some fitness test scores which could lead to a lack of inducement for the young people concerned.

- Fitness testing should promote learning (e.g. explaining the relevance of each fitness component and ensuring that children understand how to improve) and promote positive attitudes towards being active.

- It should not be assumed that fitness testing will increase pupils' activity levels. The development of lifelong activity habits should be explicitly addressed and activity promotion measures included (e.g. monitoring activity; increasing access to activity opportunities; goal-setting).

- Fitness test scores should be interpreted carefully, with recognition of their limitations.

- If standards are employed in interpreting scores, criterion referenced standards are favoured in the sense that they are attainable by the vast majority of children and reinforce the fitness-health link and the notion that one can be fit without being an elite athlete. 
- Whilst all children should be provided with feedback, it is particularly important that 'very low fit' youngsters are provided with appropriate and sensitive remedial support, encouragement and progress monitoring.

In addition, specific support and training for those likely to be involved in fitness testing children may be needed with respect to its implementation, and in particular in how to use tests and test results to achieve cognitive, affective, and behavioural objectives with children.

\section{Summary and Conclusions}


A number of key points can be summarized from the review. Firstly, a common argument in favour of testing children, namely that there are concerns over widespread low levels of fitness and the possible health consequences in children, appears to be somewhat ill founded. It is also questionable whether meaningful data can be gathered on children, given the methodological limitations in physical fitness testing and the many factors that influence children's fitness tests scores. Much of the data generated by fitness tests are problematic and not capable of rigorous interpretation. Laboratory based measures are generally considered to be more accurate, reliable and valid, but have major limitations in terms of practicality and cost. Meanwhile, it is generally accepted that field tests provide only crude measures of children's fitness and their validity, reliability, practicality and utility need to be improved.

Further, and not withstanding the methodological problems, it could be argued that the large scale national fitness surveys that have been conducted have revealed little meaningful information on children's fitness levels, or certainly limited information that can or appears to have been used to inform policy and practice. This perhaps stems from the fact that there is no consensus on the optimal level of physical fitness for young people. The fitness surveys have, however, often provided some interesting and more meaningful information on children's physical activity levels and other lifestyles behaviours. Indeed, it is interesting and perhaps of relevance that more recent developments in this area have shifted away from a focus on fitness to a focus on 'wider' lifestyle behaviours. This is in keeping with the recommendations made by a number 
of researchers who are concerned about the potential negative impact of fitness testing on the physical activity levels of some youngsters.

On a more positive note, if appropriately employed and provided all relevant factors are taken into account, fitness testing can play a role in the promotion of physical activity and in educating children about physical activity and fitness. To achieve this though, recommendations along the lines of those identified here should be followed. In addition, specific guidance, support and training for those involved in fitness testing children may be needed to assist in its successful and meaningful implementation.

The authors hope that this review will go some way to helping policy makers and practitioners better understand the complexity of 'children's fitness testing' and its possible contribution to health and activity promotion amongst young people.

\section{References}

American Alliance for Health, Physical Education, Recreation and Dance (AAHPERD). (1999a) Physical Education for Lifelong Fitness. The Physical Best Teachers' Guide. Champaign, IL: Human Kinetics. 
American Alliance for Health, Physical Education, Recreation and Dance (AAHPERD). (1999b) Physical Best Activity Guide. Secondary Level. Champaign, IL: Human Kinetics.

American Alliance for Health, Physical Education, Recreation and Dance (AAHPERD). (1999c) Physical Best Activity Guide. Elementary Level. Champaign, IL: Human Kinetics.

American College of Sports Medicine. (ACSM). (1988) Opinion statement on physical fitness in children and youth. Medicine and Science in Sport and Exercise, 20(4): 422-3.

American College of Sports Medicine. (ACSM). (2000) Exercise testing and prescription for children, the elderly, and pregnant women. In: ACSM's Guidelines for Exercise Testing and Prescription. Sixth edition, Lippincott Williams \& Wikins, pp. 217-234.

Armstrong, N. (1987) A critique of fitness testing. In: Biddle, S. (ed) Foundations of Health Related Fitness in Physical Education, London: Ling Publishing House, pp.19-27.

Armstrong, N. (1989) Is fitness testing either valid or useful? British Journal of Physical Education, 20: 66-67. 
Armstrong, N. (1995) The assessment of health-related fitness in schools.

In: Darmody, M. \& O'Donovan, G. (eds) Physical Education at the Crossroads, Limerick: PEAI, pp. 44-48.

Armstrong, N., \& Biddle, S. (1992) Health-related physical activity in the national curriculum. In: Armstrong, N. (ed) New Directions in Physical Education, Volume 2, Towards a National Curriculum, Champaign, IL: Human Kinetics, pp. 71-110.

Armstrong, N., \& Van Mechelen, W. (1998) Are young people fit and active? In: Biddle, S., Sallis, J., \& Cavill, N. (eds) Young and Active? Young People and Health-enhancing Physical Activity - Evidence and Implications, London: Health Education Authority, pp. 69-97.

Armstrong, N., \& Welsman, J.R. (1994) Assessment and interpretation of aerobic fitness in children and adolescents. Exercise and Sports Sciences Reviews, 22: 435-476.

Armstrong, N., \& Welsman, J. (1997) Young People and Physical Activity. Oxford University Press.

Armstrong, N., \& Welsman, J. (2000a) Aerobic fitness. In: Armstrong, N., \& Van Mechelen, W. (eds) Paediatric Exercise Science and Medicine, Oxford: Oxford University Press, pp. 65-75. 
Armstrong, N., \& Welsman, J.R. (2000b) Development of aerobic fitness during childhood and adolescence. Pediatric Exercise Science, 12: 128-149.

Armstrong, N., Balding, J., Gentle, P., \& Kirby, B. (1990) Estimation of coronary risk factors in British school children: a preliminary report. British Journal of Sports Medicine, 24: 61-66.

Armstrong, N., Williams, J., Balding, J., Gentle, P., \& Kirby, B. (1991) The peak oxygen uptake of British children with reference to age, sex, and sexual maturity. European Journal of Applied Physiology, 62: 369-375.

Armstrong, N., Kirby, B.J., McManus, A.M, \& Welsman, J.R. (1995) Aerobic fitness of pre-pubescent children. Annals of Human Biology, 22: 427-441.

Armstrong, N., Kirby, B., McManus, A., \& Welsman, J. (1996) Physical activity patterns and aerobic fitness among pre-pubescents. European Physical Education Review, 7: 19-29.

Astrand, P.O. (1952). Experimental Studies of Physical Working Capacity in relation to Sex and Age. Copenhagen: Munksgaard.

Baalpe (2004). Safe practice in physical education and school sport. Leeds: Coachwise. 
Bar-Or, O. (1993) Importance of differences between children and adults for exercise testing and exercise prescription. In: Skinner, J.S. (ed) Exercise Testing and Prescription for Special Cases. Second edition, Lea \& Febiger, pp. 57-74.

Bell, R.D., Macek, M., Rutenfranz, J., \& Saris, W.H.M. (1986) Health indicators and risk factors in of cardiovascular diseases during childhood and adolescence. In: Rutenfranz, J., Mocellin, R., \& Klimt, F. (eds) Children and Exercise XII, Champaign, IL: Human Kinetics, pp. 19-27.

Biddle, S. (1995) Exercise and psychosocial health. Research Quarterly for Exercise and Sport, 66: 292-297.

Biddle, S. J.H, Gorely, T., \& Stensel, D. (2004). Health-enhancing physical activity and sedentary behaviour in children and adolescents. Journal of Sports Sciences, 22, 679-701.

Blair, S.N. (1995) Youth fitness: Directions for future research. In Cheung, L.W.Y., \& Richmond, J.B. (eds) Child Health, Nutrition and Physical Activity, Champaign, IL: Human Kinetics, pp. 147-152.

Blimkie, C.J.R., \& Macauley, D. (2000) Muscle strength. In: Armstrong, N., \& Van Mechelen, W. (eds) Paediatric Exercise Science and Medicine, Oxford: Oxford University Press, pp. 23-36. 
Boreham, C., \& Riddoch, C. (2001) The physical activity, fitness and health of children. Journal of Sports Science, 19: 915-929.

Boreham, C., Twisk, J., Neville, C., Savage, M., Murray, L., \& Gallagher, A. (2002) Associations between physical fitness and activity patterns during adolescence and cardiovascular risk factors in young adulthood: The Northern Ireland Young Hearts Project. International Journal of Sports Medicine, 23 (supplement): S22-S26.

Bouchard, C., Dionne, F.T., Simoneau, J., \& Boulay, M. (1992) Genetics of aerobic and anaerobic performances. Exercise and Sport Sciences Reviews, 20: 27-58.

Cale, L., \& Harris, J. (1998) The benefits of health-related physical education and recommendations for implementation, The Bulletin of Physical Education 34(1): 27-41.

Cale, L., \& Harris, J. (2002) National fitness testing for children - issues, concerns and alternatives. The British Journal of Teaching Physical Education, 33(1): 32-34.

Cale, L., \& Harris, J. (Eds.) (2005). Exercise and young people. Issues, implications and initiatives. Basingstoke, Hampshire: Palgrave Macmillan. 
Calfas, K.J., \& Taylor, C. (1994) Effects of physical activity on psychological variables in adolescents. Pediatric Exercise Science, 6: 406-423.

Caspersen, C.J., Powell, K.E., \& Christenson, G.M. (1985) Physical activity, exercise and physical fitness: Definitions and distinctions for health-related research. Public Health Reports, 100: 126-130.

Cavill, N., Biddle, S., \& Sallis, J.F (2001) Health enhancing physical activity for young people: Statement of the United Kingdom Expert Consensus Conference. Pediatric Exercise Science, 13: 12-25.

Claessens, A.L., Beunen, G., \& Malina, R.M. (2000) Anthropometry, physique, body composition and maturity. In: Armstrong, N., \& Van Mechelen, W. (eds) Paediatric Exercise Science and Medicine, Oxford: Oxford University Press, pp. 11-21.

The Cooper Institute for Aerobics Research. (1999) FITNESSGRAM. Test Administration Manual, Second Edition. Champaign, III: Human Kinetics.

Corbin, C.B. (2002) Physical activity for everyone: what every physical educator should know about promoting lifelong physical activity. Journal of Teaching in Physical Education, 21: 128-144.

Corbin, C.B., \& Pangrazi, R.P. (1992) Are American children and youth fit? Research Quarterly for Exercise and Sport, 63(2): 96-106. 
Corbin, C.B., Pangrazi, R.P., \& Welk, G.J. (1995) A response to 'The horse is dead; let's dismount.' Pediatric Exercise Science, 7: 347-351. Council of Europe (1988). European test of physical fitness - EUROFIT. Committee for the Development of Sport. London: Sports Council.

Cureton, K. J. (1994) Physical fitness and activity standards for youth. In: Pate, R.R., \& Hohn, R.C. (eds) Health and Fitness Through Physical Education, Champaign, III: Human Kinetics, pp.129-136.

Cureton, K.J., \& Warren, G., (1990) Criterion-referenced standards for youth health-related fitness tests: a tutorial. Research Quarterly for Exercise and Sport, 61: 7-19.

Department of Health (2004). At least five a week. Evidence of the impact of physical activity and its relationship to health. A report from the Chief Medical Officer. London: Department of Health.

Division of Physical and Health Education (1990) Northern Ireland Fitness Survey. The Fitness, Physical Activity, Attitudes and Lifestyles of Northern Ireland Post Primary School Children. Belfast: Division of Physical and Health Education, The Queen's University of Belfast.

Docherty, D., \& Bell, R. (1990) Fitness testing: counterproductive to a healthy lifestyle? CAHPER Journal, 56(5): 4-8. 
Fox, K., \& Biddle, S. (1986) Health related fitness testing in schools: Introduction and problems of interpretation. The Bulletin of Physical Education, 22: 54-64.

Fox, K.R., \& Biddle, S.J.H. (1988) The use of fitness tests: educational and psychological considerations. Journal of Physical Education Recreation and Dance, 59(2): 47-53.

Goudas, M., Biddle, S., \& Fox, K. (1994) Achievement goal orientations and intrinsic motivation in physical fitness testing with children. Pediatric Exercise Science, 6: 159-167.

Hamblin, Y., \& Stubbings, R. (2003). The implementation of Metalib and SFX at Loughborough University Library. Loughborough: Library \& Information Statistics Unit.

Harris, J. (2000) Health-Related Exercise in the National Curriculum. Key Stages 1 to 4. Leeds: Human Kinetics.

Harris, J., \& Cale, L. (1997) How healthy is school PE? A review of the effectiveness of health-related physical education programmes in schools. Health Education Journal, 56: 84-104. 
Harris, J., \& Elbourn, J. (1994) Measure for measure. Does activity and fitness monitoring have a place within physical education? Sports Teacher, Autumn: 11-15.

Hasselstrom, H., Hansen, S.E., Froberg, K., \& Andersen, L.B. (2002) Physical fitness and physical activity during adolescence as predictors of cardiovascular disease risk in young adulthood: Danish Youth Sports Study: An eight-year follow-up study. International Journal of Sports Medicine, 23 (supplement): S27-S31.

Health Education Authority (HEA) (1998). Young and active? Policy framework for young people and health-enhancing physical activity. London: HEA.

Hopple, C., \& Graham, G. (1995) What children think, feel and know about physical fitness testing. Journal of Teaching in Physical Education, 14(4): 408-417.

Jackson, J.A. (2000) Fitness testing: student and teacher perspectives. FAHPERD Journal of Health, Physical Education, Recreation and Dance, 38(3): 29-31.

Janz, K.F., Dawson, J.D., \& Mahoney, L.T. (2002) Increases in physical fitness during childhood improves cardiovascular health during adolescence: The Muscatine Study. International Journal of Sports Medicine, 23 (supplement): S15-S21 
Lefevre, J., Philippaerts, R., Delvaux, K., Thomis, M., Claessens, A.L., Lysens, R., et al. (2002) Relation between cardiovascular risk factors at adult age, and physical activity during youth and adulthood. The Leuven Longitudinal Study on Lifestyle, Fitness and Health. International Journal of Sports Medicine, 23 (supplement): S32-S38.

Luke, M.D., \& Sinclair, G.D. (1991) Gender differences in adolescents' attitudes toward school physical education. Journal of Teaching in Physical Education, 11: 31-46.

Morse, M., Schlutz, F.W., \& Cassels, D.E. (1949) Relation of age to physiological responses of the older boy to exercise. Journal of Applied Physiology, 1: 683-709.

Mutrie, N., \& Parfitt, G. (1998) Physical activity and its link with mental, social and moral health in young people. In: Biddle, S., Sallis, J., \& Cavill, N. (eds) Young and Active? Young People and Health-enhancing Physical Activity Evidence and Implications, London: Health Education Authority, pp. 49-68.

Pangrazi, R.P. (2000) Promoting physical activity for youth. The ACHPER Healthy Lifestyles Journal, 47(2): 18-21. 
Pangrazi, R.P., \& Corbin, C.B. (1990) Age as a factor relating to physical fitness test performance. Research Quarterly for Exercise and Sport, 61(4): 410-414.

Pate, R.R, (1994) Fitness testing: current approaches and purposes in physical education. In: Pate, R.R., \& Hohn, R.C. (eds) Health and Fitness Through Physical Education, Champaign, Ill: Human Kinetics, pp. 119-127.

Pate, R.R. (1988) The evolving definition of physical fitness. Quest, 40: 174-179.

Pate, R.R. (1989) The case for large-scale physical fitness testing in American youth. Pediatric Exercise Science, 1: 290-294.

Pate, R.R, \& Hohn, R.C. (1994) Health-related physical education - a direction for the $21^{\text {st }}$ century. In Pate, R.R., \& Hohn, R.C. (eds) Health and Fitness Through Physical Education. Champaign, III: Human Kinetics, pp. 215-217.

Physical Education Association (PEA). (1988) Health related fitness testing and monitoring in schools. A position statement on behalf of the PEA by its fitness and health advisory committee. British Journal of Physical Education, 19(4/5): 194-195. 
Pyke, J. (1987) Australian Health and Fitness Survey. Adelaide, Australia: ACHPER.

Rice, M.H., \& Howell, C.C. (2000) Measurement of physical activity, exercise and physical fitness in children: issues and concerns. Journal of Pediatric Nursing, 15(3): 148-156.

Riddoch, C. (1998) Relationships between physical activity and physical health in young people. In: Biddle, S., Sallis, J., \& Cavill, N. (eds) Young and Active? Young People and Health-enhancing Physical Activity - Evidence and Implications, London: Health Education Authority, pp. 17-48.

Riddoch, C., \& Boreham, C.A.G. (1995) The health-related physical activity of children. Sports Medicine, 19(2): 86-102.

Robinson, S. (1938) Experimental studies of physical fitness in relation to age. Arbeitsphysiologie, 10: 251-323.

Ross, J.G. (1989) Evaluating fitness and activity assessments from the National Children and Youth Fitness Studies I and II. In: Assessing Physical Fitness and Physical Activity in Population-based Surveys. Rockville, MD: US Department of Health and Human Services, Publication (PHS) DHSS, pp. 891253. 
Ross, J.G., \& Gilbert, G.G. (1985) The National Children and Youth Fitness

Study. A Summary of Findings. Journal of Physical Education, Recreation and Dance, 56: 45-50.

Ross, J.G., \& Pate, R.R. (1987) The National Children and Youth Fitness

Study II. A Summary of Findings. Journal of Physical Education, Recreation and Dance, 58: 51-56.

Rowland, T.W. (1995) The horse is dead; let's dismount. Pediatric Exercise Science, 7: 117-120.

Rowland, T.W. (2002) Declining cardiorespiratory fitness in youth: fact or supposition? Pediatric Exercise Science, 14: 1-8.

Safrit, M. (1990) The validity and reliability of fitness tests for children: A review. Pediatric Exercise Science, 2: 9-28.

Safrit, M.J., \& Looney, M.A. (1992) Should the punishment fit the crime? A measurement dilemma. Research Quarterly for Exercise and Sport, 62: 24-127.

Seefeldt, V., \& Vogel, P. (1989) Physical fitness testing of children: A 30year history of misguided efforts. Pediatric Exercise Science, 1: 295-302. 
Shephard, R.J. (1986) Fitness of a Nation: Lessons from the Canada Fitness Survey. In: Hebbelinck, M., \& Shephard, R.J. (eds) Medicine and Sports Science, New York: Karger.

Stephens, T., \& Craig, C.I. (1988). The Well Being of Canadians: Highlights of the Campbells' Survey. Ottawa: Canadian Fitness and Lifestyle Research Institute.

Torrance, G.M. (1991) Campbell Survey Results for Youth. Fitness Development Unit Fitness Canada.

Tortolero, S.R., Taylor, W.C., \& Murray, N.G. (2000). Physical activity, physical fitness and social, psychological and emotional health. In: Armstrong, N., \& Van Mechelen, W. (eds) Paediatric Exercise Science and Medicine, Oxford: Oxford University Press, pp. 273-293.

Twisk, J.W.R. (2000). Physical activity, physical fitness and cardiovascular health. In: Armstrong, N., \& Van Mechelen, W. (eds) Paediatric Exercise Science and Medicine, Oxford: Oxford University Press, pp. 253-263.

Twisk, J.W.R., Kemper, H.C.G., \& Van Mechelen, W. (2002a) The relationship between physical fitness and physical activity during adolescence and cardiovascular disease risk factors at adult age: The Amsterdam Growth and Health Longitudinal Study. International Journal of Sports Medicine, 23(supplement): S8-S14. 
Twisk, J.W.R., Kemper, H.C.G., \& Van Mechelen, W. (2002b) Prediction of cardiovascular disease risk factors in later life by physical activity and physical fitness in youth: General comments and conclusions. International Journal of Sports Science, 23(supplement): S440-S50.

Updyke, W.F. (1992) In search of relevant and credible physical fitness standards for children. Research Quarterly for Exercise and Sport, 63(2): 112-119.

US Department of Health and Human Services. (1986) 1985 President's Council on Physical Fitness and Sports Youth Survey. Washington, DC: US Government Printing Office.

Welsman, J., \& Armstrong, N. (1996) The measurement and interpretation of aerobic fitness in children: current issues. Journal of the Royal Society of Medicine, 89: 281-285.

Whitehead, J.R., \& Corbin, C.B. (1991) Youth fitness testing: the effect of percentile-based evaluative feedback on intrinsic motivation. Research Quarterly for Exercise and Sport, 62: 225-231.

Whitehead, JR., Pemberton, C.L., \& Corbin, C.B. (1990) Perspectives on the physical fitness testing of children: The case for a realistic educational approach. Pediatric Exercise Science, 2: 111-123. 
www.cflri.ca: Canadian Fitness and Lifestyle Research Institute; 05/10/05. 
Table 1: A Selection of Children's National Fitness Surveys

\begin{tabular}{|c|c|c|c|c|c|}
\hline Survey & Aim(s) & Sample & Method & $\begin{array}{c}\text { Summary of findings } \\
\text { (fitness only) }\end{array}$ & Conclusions (fitness only) \\
\hline \begin{tabular}{l|} 
Northern \\
Ireland \\
Fitness \\
Survey (1989)
\end{tabular} & $\begin{array}{l}\text { 1) To obtain benchmark } \\
\text { data on the lifestyles, } \\
\text { attitudes, fitness levels, } \\
\text { activity levels, dietary habits } \\
\text { and health knowledge of } \\
\text { Northern Ireland school } \\
\text { children; } \\
\text { 2) To create an educational } \\
\text { package for use in schools } \\
\text { that might encourage } \\
\text { children to increase their } \\
\text { knowledge of, and acquire } \\
\text { positive attitudes towards, } \\
\text { healthy living, exercise and } \\
\text { fitness. }\end{array}$ & $\begin{array}{l}3211 \text { children } \\
\text { (11-18 years) }\end{array}$ & $\begin{array}{l}\text { Survey instruments comprised: } \\
\text { 1) a battery of } 9 \text { field tests of } \\
\text { physical fitness (taken from the } \\
\text { Eurofit battery); } \\
\text { 2) a laboratory treadmill test of } \\
\text { aerobic power; } \\
\text { 3) A 'lifestyle' questionnaire } \\
\text { (covering physical activity, } \\
\text { children's lifestyle, and health } \\
\text { knowledge and beliefs) and an } \\
\text { 'attitudes' questionnaire (covering } \\
\text { children's attitudes towards sport } \\
\text { and exercise, plus social } \\
\text { psychological factors of children's } \\
\text { involvement in exercise). }\end{array}$ & $\begin{array}{l}\text { Boys were reported to have a } \\
\text { higher opinion of their fitness and } \\
\text { health status than girls. } \\
\text { The fitness levels of the children } \\
\text { were found to be generally similar } \\
\text { to the fitness levels of children of } \\
\text { the same age and sex reported in } \\
\text { other national surveys (Canada, } \\
\text { US, Australia). } \\
\text { There was some evidence to } \\
\text { suggest that Northern Ireland } \\
\text { children are leaner than their } \\
\text { foreign counterparts. }\end{array}$ & $\begin{array}{l}\text { It is difficult to draw any definite } \\
\text { conclusions about the fitness } \\
\text { status of Northern Ireland } \\
\text { school children from the results } \\
\text { obtained. It is not possible to } \\
\text { say, for example, whether } \\
\text { children are 'fit enough.' } \\
\text { BUT... } \\
\text { Children exhibit a considerable } \\
\text { range of fitness scores and } \\
\text { there are likely to be significant } \\
\text { numbers of children for whom } \\
\text { fitness levels are inadequate. }\end{array}$ \\
\hline $\begin{array}{l}\text { The National } \\
\text { Children and } \\
\text { Youth Fitness } \\
\text { Study I (1985) }\end{array}$ & $\begin{array}{l}\text { 1) To describe the current } \\
\text { fitness status of American } \\
\text { children and youth and the } \\
\text { patterns of participation in } \\
\text { physical activity; } \\
\text { 2) To evaluate the } \\
\text { relationships between } \\
\text { physical activity patterns } \\
\text { and measured fitness. }\end{array}$ & $\begin{array}{l}\text { 8,800 children } \\
\text { (10-18 years). }\end{array}$ & $\begin{array}{l}\text { Children completed: } \\
\text { 1) a physical activity questionnaire } \\
\text { (covering the frequency, duration } \\
\text { and seasonality of exercise, sport } \\
\text { and activity participation through } \\
\text { PE, other school programmes, } \\
\text { community organisations and the } \\
\text { neighbourhood); } \\
\text { 2) a battery of } 5 \text { tests of physical } \\
\text { fitness (skinfolds, sit and reach, } \\
\text { bent knee sit ups, chin ups, mile } \\
\text { walk run). }\end{array}$ & $\begin{array}{l}\text { Average scores were reported for } \\
\text { each test item. Norms by sex/age } \\
\text { and sex/grade for each measure } \\
\text { were produced. } \\
\text { An increase in body fat was } \\
\text { detected compared to national } \\
\text { data obtained in the } 1960 \text { s. } \\
\text { Performance on a number of } \\
\text { fitness tests improved with age for } \\
\text { both boys and girls. This pattern } \\
\text { of continued improvement runs } \\
\text { contrary to the common belief that } \\
\text { performance on fitness tests } \\
\text { levels off for boys and declines for }\end{array}$ & $\begin{array}{l}\text { The survey has produced a } \\
\text { substantial base of knowledge } \\
\text { about physical fitness (and } \\
\text { activity patterns) of children and } \\
\text { youth. } \\
\text { Co-ordinated efforts are } \\
\text { required to accomplish the } \\
\text { objectives for the nation related } \\
\text { to fitness and exercise among } \\
\text { children and youth. }\end{array}$ \\
\hline
\end{tabular}




\begin{tabular}{|c|c|c|c|c|c|}
\hline & & & & $\begin{array}{l}\text { girls in early adolescence. } \\
\text { Variables related to the PE } \\
\text { programme, community } \\
\text { organisations and appropriate } \\
\text { physical activity all exerted an } \\
\text { influence on fitness levels. }\end{array}$ & \\
\hline $\begin{array}{l}\text { The National } \\
\text { Children and } \\
\text { Youth Fitness } \\
\text { Study II } \\
\text { (1987) }\end{array}$ & $\begin{array}{l}\text { An extension of the first } \\
\text { survey to younger children. } \\
\text { Specific questions included: } \\
\text { 1) How do children in grades } \\
\text { 1-4 perform on health- } \\
\text { related tests of physical } \\
\text { fitness? } \\
\text { 2) What are the physical } \\
\text { activity habits of children at } \\
\text { home, at school, and in the } \\
\text { community? } \\
\text { 3) What factors, including } \\
\text { exercise habits, affect } \\
\text { measured fitness? }\end{array}$ & $\begin{array}{l}4,678 \text { children } \\
\text { (6-9 years) in } 19 \\
\text { states (plus } \\
4435 \text { parents). }\end{array}$ & $\begin{array}{l}\text { Parents completed a survey } \\
\text { questionnaire describing their own } \\
\text { and their child's activity patterns. } \\
\text { Information about the school PE } \\
\text { programmes was collected from } \\
\text { teachers. } \\
\text { Children completed a modified set } \\
\text { of the fitness tests used in the } \\
\text { previous study (e.g., modified pull } \\
\text { ups replaced chin ups; children } \\
\text { under } 8 \text { completed a half mile } \\
\text { run/walk). }\end{array}$ & $\begin{array}{l}\text { Descriptive data and fitness } \\
\text { norms were produced. } \\
\text { Increases in body fat were } \\
\text { evident compared to national data } \\
\text { obtained in the 1960s. } \\
\text { The physical activity patterns of } \\
\text { children (as reported by their } \\
\text { parents and teachers) were } \\
\text { significantly related to their } \\
\text { physical fitness. }\end{array}$ & $\begin{array}{l}\text { The survey has provided } \\
\text { information never before } \\
\text { available about physical fitness, } \\
\text { physical activity patterns and } \\
\text { factors related to the physical } \\
\text { fitness of children (grades 1-4). } \\
\text { The information suggests that } \\
\text { current programmes may be } \\
\text { inadequate to promote lifetime } \\
\text { fitness. Findings challenge } \\
\text { policy makers, researchers, } \\
\text { teachers and community } \\
\text { members to make informed } \\
\text { decisions about actions needed } \\
\text { to enhance children's future } \\
\text { fitness and physical activity. }\end{array}$ \\
\hline $\begin{array}{l}\text { The } 1981 \\
\text { Canada } \\
\text { Fitness } \\
\text { Survey }\end{array}$ & $\begin{array}{l}\text { To determine the physical } \\
\text { recreation habits, physical } \\
\text { fitness and health status of } \\
\text { an entire population and } \\
\text { establish baseline data. }\end{array}$ & \begin{tabular}{l|} 
More than \\
23000 \\
Canadians $(7$ \\
years and older).
\end{tabular} & $\begin{array}{l}\text { During a household visit, } \\
\text { participants completed a physical } \\
\text { activity and lifestyle questionnaire } \\
\text { and undertook a series of fitness } \\
\text { tests known as the Canadian } \\
\text { Standardized Test of Fitness. }\end{array}$ & $\begin{array}{l}\text { The published results focused } \\
\text { primarily on physical activity } \\
\text { levels, reasons for and barriers to } \\
\text { participating, as well as lifestyle. }\end{array}$ & $\begin{array}{l}\text { There were no clear } \\
\text { conclusions relating to fitness } \\
\text { data. }\end{array}$ \\
\hline $\begin{array}{l}\text { The } 1988 \\
\text { Campbell } \\
\text { Survey on } \\
\text { Well Being in } \\
\text { Canada }\end{array}$ & $\begin{array}{l}\text { 1) To provide an update of } \\
\text { the } 1981 \text { Canada Fitness } \\
\text { Survey information; } \\
\text { 2) To examine the } \\
\text { contribution of exercise to } \\
\text { health; }\end{array}$ & $\begin{array}{l}4000 \\
\text { respondents (the } \\
\text { majority of whom } \\
\text { had participated } \\
\text { in the } 1981 \\
\text { survey). }\end{array}$ & As per the 1981 Survey. & $\begin{array}{l}\text { Percentile distributions of fitness } \\
\text { variables by sex and age were } \\
\text { presented. The reported findings } \\
\text { for youth and young adults } \\
\text { focused on physical activity } \\
\text { levels, factors important to health, }\end{array}$ & $\begin{array}{l}\text { There were no clear } \\
\text { conclusions relating to fitness } \\
\text { data. }\end{array}$ \\
\hline
\end{tabular}




\begin{tabular}{|l|l|l|l|}
\hline $\begin{array}{l}\text { 3) To investigate adherence } \\
\text { over time to regular physical } \\
\text { activity; } \\
\text { 4) To identify changes in } \\
\text { patterns of activity and } \\
\text { fitness between 1981-1988. }\end{array}$ & & & $\begin{array}{l}\text { emotional well being and } \\
\text { depression, and self-rated health } \\
\text { status. }\end{array}$ \\
\hline
\end{tabular}

